ISSN 0258-7122

Bangladesh J. Agril. Res. 38(1): 137-143, March 2013

\title{
STUDY ON INTERCROPPING LEAFY VEGETABLES WITH OKRA (Abelmoschus esculentus L.)
}

\author{
F. AHMED ${ }^{1}$, M. N. ISLAM ${ }^{3}$, M. S. ALOM ${ }^{1 *}$ \\ M. A. I. SARKER ${ }^{2}$, AND M. A. MANNAF ${ }^{4}$
}

\begin{abstract}
A field experiment on intercropping of okra and leafy vegetables was conducted at Bangladesh Agricultural Research Institute (BARI), Joydebpur, Gazipur and Agricultural Research Station, Burirhat, Rangpur during Kharif-I season of 2010 and 2011 to find out suitable crop combination for higher productivity and economic return. Seven treatments viz., sole okra $(50 \mathrm{~cm} \times 40 \mathrm{~cm})$, okra $100 \%$ (in row) + red-amaranth $100 \%$ (broadcast), okra 100\% (in row) + red-amaranth 75\% (broadcast), okra 100\% (in row) + leaf amaranth 100\% (broadcast), okra $100 \%$ (in row) + leaf amaranth 75\% (broadcast), okra 100\% (in row) + jute as patshak 100\% (broadcast), okra 100\% (in row) + jute as patshak $75 \%$ (broadcast) were used. Intercropping reduced okra yield but total productivity increased due to additional yield of vegetables. In both the locations, sole okra produced the highest yields (15.82 t/ha at Joydebpur and 13.79 t/ha at Burirhat). Among the intercropping treatments, the highest okra yields (15.42 t/ha at Joydebpur and $12.64 \mathrm{t} / \mathrm{ha}$ at Burirhat) were obtained from okra $100 \%+$ red amaranth $75 \%$ combination. The lowest okra yield (13.16 t/ha at Joydebpur and $11.75 \mathrm{t} / \mathrm{ha}$ at Burirhat) was recorded in okra $100 \%+$ jute as patshak $100 \%$ combination. The highest okra equivalent yield (23.00 t/ha) was recorded in okra $100 \%$ + red amaranth $100 \%$ at Joydebpur and in okra $100 \%+$ leaf amaranth $100 \%$ (21.79 t/ha) at Burirhat. These treatment combinations also gave the highest gross margin (Tk. 227180/ha at Joydebpur and Tk. 214600/ha at Burirhat) and benefit cost ratio (5.66 at Joydebpur and 5.58 at Burirhat). The results revealed that cent percent red amaranth (broadcast) or leaf amaranth intercropped with cent percent okra might be suitable combination for higher productivity and economic return at Joydebpur and Burirhat, respectively.
\end{abstract}

Keywords: Okra, leafy vegetables and intercropping.

\section{Introduction}

Intercropping is a tool used for increasing cropping intensity in developing countries like Bangladesh. It increases total productivity through efficient utilization of land, labour, and growth resources (Ahmed et al., 2006). Greater productivity in intercropping system is commonly achieved by minimizing inter-

${ }^{1}$ Senior Scientific Officer, Agronomy Division, Bangladesh Agricultural Research Institute (BARI), Gazipur, ${ }^{2}$ Senior Scientific Officer, Burirhat, BARI, Rangpur, ${ }^{3}$ Principal Scientific Officer, Agronomy Division, BARI, Gazipur and ${ }^{4}$ Principal Scientific Officer, Burirhat, BARI, Rangpur, Bangladesh. 
specific competition and maximizing complementary use of growth resources (Islam, 2002). Inter-specific competition may be minimized through judicious choice of crops (Santalla et al., 2001). Usually plants differing in growth duration, height, rooting systems, and nutrient requirements are considered to grow together in intercropping systems (Reddy and Willey, 1981). Okra (Abelmoschus esculentus L.) is an important summer vegetable crop in Bangladesh, which is grown in Kharif-I season (February/March). Okra is a tall statured crop and is grown with wide spacing. So, short duration vegetables like red-amaranth, leaf amaranth (danta shak) and jute (patshak) may be introduced as intercrop by utilizing the inter-row space of okra for crop diversity and higher economic return. Summer vegetables crises may also be met up to some extent by intercropping of leafy vegetables with okra. Most intercropping research has focused on field crops (Tsubo et al., 2005 and Ghosh et al., 2006). Intercropping field crops with vegetables has also been intensively investigated (Ahmed et al. 2006 ; El-shaikh and Bekheet, 2004). However, relatively few studies have been conducted on vegetables plus vegetables intercropping systems. Therefore, this experiment was conducted to find out suitable crop combination for intercropping system along with proportion for higher productivity and economic return.

\section{Materials and Method}

The experiment was conducted at the research field of Agronomy Division, BARI, Joydebpur, Gazipur of Grey Terrace soil (AEZ-28) and Agricultural Research Station, Burirhat, Rangpur of Tista Meander Floodplain soil (AEZ-3) during the Kharif-I season of 2010 and 2011. Seven treatments viz. Sole okra (50 $\mathrm{cm} \times 40 \mathrm{~cm}$ ), okra 100\% (in row) + red-amaranth 100\% (broadcast), okra 100\% (in row) + red-amaranth 75\% (broadcast), okra 100\% (in row) + leaf amaranth $100 \%$ (broadcast), okra 100\% (in row) + leaf amaranth 75\% (broadcast), okra $100 \%$ (in row) + jute as patshak 100\% (broadcast), okra 100\% (in row) + jute as patshak $75 \%$ (broadcast) were used. The unit plot size was $3.5 \mathrm{~m} \mathrm{x} 4 \mathrm{~m}$. The experiment was laid out in randomized completely block design with three replications. Seeds of okra (Green finger), red amaranth (var. BARI Lalshak-1), leaf amaranth (var. BARI Danta-1) and patshak (var. Binapatshak-1) were sown according to treatments on 10 March 2010 and 15 March 2011 at Joydebpur and 20 March 2010 and 19 March 2011 at Burirhat. Seed rate/ha were used as 5.0, 3.0, 3.0 and $15.0 \mathrm{~kg}$ for okra, red amaranth, leaf amaranth and jute, respectively. Fertilizers were applied in sole and intercrop plots at the rate of 90-30-60-15 $\mathrm{kg} / \mathrm{ha} \mathrm{N}, \mathrm{P}, \mathrm{K}$, and $\mathrm{S}$ as urea, triple super phosphate (TSP), muriate of potash (MoP) and gypsum, respectively. Half of urea and all other fertilizers were used as basal. Remaining urea was applied around okra plant as top dress in two equal 
split at $3^{\text {rd }}$ and $5^{\text {th }}$ weeks after sowing followed by irrigation. Red amaranth was harvested at 21 and 23 days after sowing (DAS) while leaf amaranth at 30 and 33 DAS; and jute (patshak) at 35 and 34 DAS, respectively, in 2010 and 2011. First harvest of okra was done at 40 and 48 DAS and harvesting was continued up to 136 and 124 DAS, respectively, in 2010 and 2011. The yield components data of okra were collected from 10 randomly selected plants from each plot. Collected data were analyzed statistically and mean separation was done by LSD test. Okra equivalent yield (OEY) was calculated as follows (Prasad and Srivastava, 1991).

OKY $(\mathrm{t} / \mathrm{ha})=$ Yield of okra $+\frac{\text { Yield of intercrop vegetables } \times \text { market price of vegetables }}{\text { Market price of okra }}$

Weather, especially rainfall was well distributed in 2010 (March 0 mm, April $52 \mathrm{~mm}$, May 301mm, June 494mm) that helps proper growth and development of the crops. But crop received comparatively less rainfall in 2011 (March $0 \mathrm{~mm}$, April $0 \mathrm{~mm}$, May $228 \mathrm{~mm}$, June $99 \mathrm{~mm}$ ) as a result supplemental irrigation was applied for proper growth and development of the crops.

\section{Results and Discussion}

Results obtained for the two years were almost similar and therefore pooled.

\section{Yield and yield component of okra}

Fruit length, number of fruits/plant and fruit yield of okra as influenced by intercropping system are presented in Table 1. Comparatively high fruit length was recorded in sole okra but it did not vary significantly due to intercropping at both the locations. Fruit length varied from 11.49 to $12.56 \mathrm{~cm}$ in different treatments at Joydebpur, while 10.96 to $11.94 \mathrm{~cm}$ at Burirhat. Number of fruits/plant in different treatments at Joydebpur was statistically identical and it ranged from 30 to 34 across the treatments but intercropping showed significant influence on number of fruits/plant at Burirhat. The maximum number of fruits/plant was observed in sole okra (38.50) and it was statistically identical with okra $100 \%$, + red-amaranth $100 \%$, okra $100 \%$ + amaranth $75 \%$, and okra $100 \%+$ leaf amaranth $75 \%$ combination. The lowest number of fruits/plant was recorded in okra $100 \%$ + jute as patshak $100 \%$ combination.

Fruit yield/ha varied significantly due to intercropping system. At Joydebpur, higher fruit yield (15.82 t/ha) was recorded in sole okra, which was statistically identical with okra $100 \%$ + red-amaranth $100 \%$, okra $100 \%$ + amaranth $75 \%$ and okra $100 \%$ + leaf-amaranth $75 \%$ combinations. The lowest fruit yield $(13.16$ $\mathrm{t} / \mathrm{ha}$ ) was found in okra $100 \%+$ jute as patshak $100 \%$ followed by okra $100 \%+$ leaf-amaranth $100 \%$, okra $100 \%+$ amaranth $75 \%$ combinations. Almost similar 
results were found at Burirhat location where the highest fruit yield (13.79 t/ha) was recorded in sole okra, which was statistically identical with okra $100 \%+$ red-amaranth $100 \%$ or $75 \%$ and okra $100 \%$ + leaf-amaranth or jute as parshak $75 \%$. The lowest fruit yield (11.75 t/ha) was recorded in okra $100 \%+$ jute as patshak 100\% combination. Okra yield was reduced (3 to 15\%) by intercropping probably because of competition of the two crops in mixture for growth resources. Muoneke and Ndukwe (2008) and Manga et al., (2003) also reported similar results in intercropping systems.

Table 1. Yield components and fruit yield of okra as influenced by okra and leafy vegetables intercropping (pooled).

\begin{tabular}{|c|c|c|c|c|c|c|}
\hline \multirow[t]{2}{*}{ Treatments } & \multicolumn{2}{|c|}{$\begin{array}{l}\text { Fruit length } \\
\quad(\mathrm{cm})\end{array}$} & \multicolumn{2}{|c|}{$\begin{array}{l}\text { Fruits/ plant } \\
\text { (no.) }\end{array}$} & \multicolumn{2}{|c|}{ Fruit yield (t/ha) } \\
\hline & Joydebpur & Burirhat & Joydebpur & Burirhat & Joydebpur & Burirhat \\
\hline Sole okra & 12.56 & 11.94 & 34.00 & 38.50 & 15.82 & 13.79 \\
\hline $\begin{array}{l}\text { Okra } 100 \%+\text { red- } \\
\text { amaranth } 100 \%\end{array}$ & 12.55 & 11.05 & 34.00 & 36.50 & 15.31 & 12.72 \\
\hline $\begin{array}{l}\text { Okra } 100 \%+\text { red- } \\
\text { amaranth } 75 \%\end{array}$ & 12.14 & 11.14 & 31.00 & 36.00 & 15.42 & 12.64 \\
\hline $\begin{array}{l}\text { Okra } 100 \% \text { + leaf } \\
\text { amaranth } 100 \%\end{array}$ & 11.80 & 10.74 & 30.00 & 31.50 & 13.71 & 11.86 \\
\hline $\begin{array}{l}\text { Okra } 100 \% \text { + leaf } \\
\text { amaranth } 75 \%\end{array}$ & 11.70 & 11.52 & 31.00 & 35.50 & 14.68 & 12.55 \\
\hline $\begin{array}{l}\text { Okra } 100 \%+\text { jute as } \\
\text { patshak } 100 \%\end{array}$ & 12.25 & 11.06 & 30.00 & 30.50 & 13.16 & 11.75 \\
\hline $\begin{array}{l}\text { Okra } 100 \%+\text { jute as } \\
\text { patshak } 75 \%\end{array}$ & 11.49 & 10.96 & 31.00 & 33.50 & 14.18 & 12.34 \\
\hline LSD (0.05) & NS & NS & NS & 4.30 & 1.48 & 1.46 \\
\hline CV (\%) & 7.20 & 6.20 & 6.80 & 6.99 & 5.80 & 6.6 \\
\hline
\end{tabular}

NS = Not significant.

\section{Okra equivalent yield}

Okra yields, vegetables yields, and okra equivalent yields of both the locations are presented in Table 2. Cent percent leafy vegetables intercropped with okra produced higher yield than those of $75 \%$. However, vegetables yield ranged from 6.59 to 10.17 t/ha at Joydebpur, while it ranged from 6.90 to $14.90 \mathrm{t} / \mathrm{ha}$ at Burirhat. Among the vegetables, leaf amaranth yield was higher than others at both the locations. 
Table 2. Yield of main (okra) \& intercrop (vegetables) and okra equivalent yield in intercropping system (pooled).

\begin{tabular}{l|cc|c|c|cc}
\hline \multicolumn{1}{c|}{ Treatments } & \multicolumn{2}{c|}{$\begin{array}{c}\text { Okra yield } \\
(\mathrm{t} / \mathrm{ha})\end{array}$} & \multicolumn{2}{c|}{$\begin{array}{c}\text { Vegetable yield } \\
(\mathrm{t} / \mathrm{ha})\end{array}$} & \multicolumn{2}{c}{$\begin{array}{c}\text { Okra equivalent } \\
\text { yield }(\mathrm{t} / \mathrm{ha})\end{array}$} \\
\hline & Joydebpur & Burirhat & Joydebpur & Burirhat & Joydebpur & Burirhat \\
\hline Sole okra & 15.82 & 13.79 & - & - & 15.82 & 13.79 \\
$\begin{array}{l}\text { Okra 100\% + red- } \\
\text { amaranth 100\% }\end{array}$ & 15.31 & 12.72 & 9.23 & 10.86 & 23.00 & 19.95 \\
$\begin{array}{l}\text { Okra 100\% + red- } \\
\text { amaranth 75 \% }\end{array}$ & 15.42 & 12.64 & 6.59 & 9.25 & 20.91 & 18.80 \\
$\begin{array}{l}\text { Okra 100\% + leaf } \\
\text { amaranth 100\% }\end{array}$ & 13.71 & 11.86 & 10.17 & 14.90 & 22.19 & 21.79 \\
$\begin{array}{l}\text { Okra 100\% + leaf } \\
\text { amaranth 75\% }\end{array}$ & 14.68 & 12.55 & 9.38 & 11.85 & 22.50 & 20.45 \\
$\begin{array}{l}\text { Okra 100\% + jute as } \\
\text { patshak 100\% }\end{array}$ & 13.16 & 11.75 & 8.55 & 6.90 & 20.29 & 16.35 \\
$\begin{array}{l}\text { Okra 100\% + jute as } \\
\text { patshak 75\% }\end{array}$ & 14.18 & 12.34 & 7.71 & 6.06 & 20.61 & 16.37 \\
\hline
\end{tabular}

Gazipur selling price $(\mathrm{Tk} . / \mathrm{kg})$ : Okra $=.12 .00$; Vegetables $=10.00$

Burirhat selling price (Tk./kg): Okra $=12.00$; Vegetables $=8.00$

Total productivity was expressed in okra equivalent yield. The highest okra equivalent yield (23.00 t/ha) was recorded in okra $100 \%+$ red amaranth $100 \%$ combination followed by okra 100\% + leaf amaranth $75 \%(22.50 \mathrm{t} / \mathrm{ha}$ at Joydebpur location. At Burirhat, the highest okra equivalent yield (21.79 t/ha) was found in okra $100 \%$ + leaf amaranth $100 \%$ followed by okra $100 \%$ + leaf amaranth75\% (20.45 t/ha ) combination. At both the locations, okra 100\% + jute as patshak $100 \%$ or $75 \%$ gave the lowest okra equivalent yield. Intercropping increased total productivity by 28 to $45 \%$ over sole okra. Muoneke and Mbah (2011) also reported 25-30\% yield advantage in okra/cassava intercropping in Africa.

\section{Cost benefits analysis}

Gross return, gross margin, and benefit cost ratio (BCR) is shown in Table 3. The result showed that sole okra was lower in economic analysis than any of intercrop treatment indicates intercropping advantage at both the locations.

At Joydebpur, the maximum gross return (Tk. 276000/.ha) was recorded in $100 \%$ okra $+100 \%$ red-amaranth followed by okra $100 \%$ + leaf amaranth $75 \%$ (Tk. 270000/.ha) while at Burirhat, the highest gross return (Tk.261420/ha) was recorded in okra $100 \%$ + leaf amaranth $100 \%$ combination. The lowest gross returns at both the locations were recorded in okra $100 \%$ + jute as patshak $100 \%$ (Tk. 243480/.ha at Joydebpur and Tk. 196160/ha at Burirhat). Cultivation cost of 
sole okra was lower than intercropping but additional yield of vegetables increased the profitability of intercropping over sole okra. The highest BCR (5.66) was recorded in okra $100 \%$ + red-amaranth $100 \%$ or okra $100 \%+$ leaf amaranth $75 \%$ followed by okra $100 \%+$ leaf amaranth $100 \%(5.45)$ at Joydebpur while at Burirhat, the highest BCR (5.58) was recorded in okra $100 \%$ + leaf amaranth 100\% followed by okra 100\% + leaf amaranth75\% (5.37). At both the locations, the lowest BCR (4.28 at Joydebpur and 3.91 at Burirhat) was recorded in sole okra.

Table 3. Cost benefit analysis of okra and leafy vegetables intercropping (pooled).

\begin{tabular}{|c|c|c|c|c|c|c|c|c|}
\hline \multirow[t]{2}{*}{ Treatments } & \multicolumn{2}{|c|}{$\begin{array}{l}\text { Gross return } \\
\text { (Tk./ha) }\end{array}$} & \multicolumn{2}{|c|}{$\begin{array}{l}\text { Cultivation cost } \\
\text { (Tk./ha) }\end{array}$} & \multicolumn{2}{|c|}{$\begin{array}{c}\text { Gross margin } \\
\text { (Tk./ha) }\end{array}$} & \multicolumn{2}{|c|}{ BCR } \\
\hline & Joy & Buri & Joy & Buri & Joy & Buri & Joy & Buri \\
\hline Sole okra & 189840 & 165480 & 44320 & 42320 & 145520 & 123160 & 4.28 & 3.91 \\
\hline $\begin{array}{l}\text { Okra } 100 \% \text { + red- } \\
\text { amaranth } 100 \%\end{array}$ & 276000 & 239420 & 48820 & 46820 & 227180 & 192600 & 5.66 & 5.11 \\
\hline $\begin{array}{l}\text { Okra } 100 \%+\text { red- } \\
\text { amaranth } 75 \%\end{array}$ & 250920 & 225620 & 47695 & 45695 & 203225 & 179925 & 5.26 & 4.94 \\
\hline $\begin{array}{l}\text { Okra } 100 \% \text { + leaf } \\
\text { amaranth } 100 \%\end{array}$ & 266280 & 261420 & 48820 & 46820 & 217460 & 214600 & 5.45 & 5.58 \\
\hline $\begin{array}{l}\text { Okra } 100 \% \text { + leaf } \\
\text { amaranth } 75 \%\end{array}$ & 270000 & 245360 & 47695 & 45695 & 222305 & 199665 & 5.66 & 5.37 \\
\hline $\begin{array}{l}\text { Okra } 100 \% \text { + jute } \\
\text { as patshak } 100 \%\end{array}$ & 243480 & 196160 & 50020 & 48020 & 193460 & 148140 & 4.87 & 4.08 \\
\hline $\begin{array}{l}\text { Okra } 100 \%+\text { jute } \\
\text { as patshak } 75 \%\end{array}$ & 247320 & 196460 & 48595 & 46595 & 198725 & 149865 & 5.09 & 4.22 \\
\hline
\end{tabular}

Joy $=$ Joydebpur, Buri $=$ Burirhat, $\mathrm{BCR}=$ Benefit cost ratio

Results revealed that intercropping of okra and leafy vegetables could increase total productivity and economic return over sole okra. However, cent percent broadcast red amaranth or leaf amaranth intercropping with cent percent okra (as row crop) might be suitable combination for higher productivity as well as economic return for Joydebpur and Burirhat areas. Farmers could be motivated to grow leafy vegetables in okra field as intercrop instead of growing of sole crop.

\section{References}

Ahmed, F., M.A. Rahman, M.A.H.S. Jahan, M. Ahmed and M.A. Khayer. 2006. Effect of different planting systems in maize/spinach-red amaranth intercropping. Bangladesh J. Agric. and Environ. 2(2): 69-76.

EL-Shikh, K.A. A. and M. A. Bekheet. 2004. Effect of intercropping faba bean and garlic on sugar beet in the newly reclaimed soils. Assiut J. Agric. Sci. 35(4): 187-204. 
Ghosh, P. K., M. Mohanty, K. K. Bandyopadhyay, D. K. Painuli and A. K. Misra. 2006. Growth, competition, yield advantage and economics in soybean/ pigeonpea intercropping system in semi-arid tropics of India: I. Effect of subsoiling. Field Crops Res. 96:80-89.

Islam, M. N. 2002. Competitive interference and productivity in maize-bushbean intercropping system. A Ph.D. Dissertation, Dept. of Agronomy, Bangabandhu Sheikh Mujibur Rahman Agricultural University, Gazipur.

Manga, A.A., M.G. Bala, and L.W. Ashafa. 2003. Evaluation of maize (Zea mays L.) and grain amaranth (Amaranthus cruentus L.) intercrop. Nigerian J. Hort.Sci. 8: 7-10.

Muoneke, C.O. and O.O. Ndukwe. 2008. Effect of plant population and spatial arrangement on the productivity of okra/amaranthus intercropping system. J. Trop Agric. Food, Environ and Extn. 7(1): 15-21.

Prasad, K and R.C. Srivastava. 1991. Pigeon pea (Cajanus cajan) and soybean (Glycine max) intercropping system under rainfed situation. Indian J. Agric. Sci., 61: 243-246.

Reddy, M.S. and R. W. Willey. 1981. Growth and resource use studies in an intercrop of pearl millet/groundnut. Field Crops Res. 4:13-24.

Santalla, M., A. P. Rodino, P. A. Casquero, and A. M. De Ron. 2001. Interactions of bushbean intercropped with field and sweet maize. European J. Agron. 15 : 185-196.

Tsubo, M., S. Walker and H. O. Ogindo. 2005. A simulation model of cereal-legume intercropping system for semi-arid regions II. Model application. Field Crops Res. 93:23-33.

Muoneke C.O. and E.U. Mbah. 2011. Productivity of cassava/okra intercropping systems as influenced by okra planting density the component species. African J. Agril Res. 2(5): 223-231. 